\title{
PEMBUATAN APLIKASI CHATBOT KOLEKTOR DENGAN METODE EXTREME PROGRAMMING DAN STRATEGI FORWARD CHAINING.
}

\author{
Muhamad Sidik*1, Bambang Gunawan $^{2}$, Dina Anggraini ${ }^{3}$ \\ 1,2,3 Magister Manajemen Sistem Informasi, Universitas Gunadarma Depok \\ Email: ${ }^{1}$ m.sidik19@yahoo.com, ${ }^{2}$ bambang_gunawan@ @taff.gunadarma.ac.id, \\ 32dina_anggraini@ @staff.gunadarma.ac.id \\ *Penulis Korespondensi
}

(Naskah masuk:05 November 2020, diterima untuk diterbitkan: 22 Maret 2021)

\begin{abstract}
Abstrak
Permintaan layanan informasi pada suatu bagian dalam satu perusahaan tentu menjadi sebuah kegiatan yang rutin terjadi, namun jika permintaan layanan informasi dilakukan dalam jumlah yang banyak tentu akan menjadi sebuah masalah. Untuk menangani permasalahan menumpuknya permintaan layanan informasi seperti keluhan pelanggan, permintaan data konsumen, pelayanan nasabah baru, dan permasalahan serupa maka banyak diterapkan bantuan asisten virtual atau biasa disebut dengan chatbot. Chatbot merupakan aplikasi asisten virtual yang mampu melakukan interaksi secara langsung kepada setiap pesan yang masuk tanpa perlu menunggu operator untuk membalas pesan-pesan tersebut, sehingga chatbot merupakan solusi yang dinilai efektik untuk menangani permasalahan dalam permintaan layanan informasi yang menumpuk. Selain itu, pengembangan chatbot juga berguna untuk memberikan layanan pemberian informasi yang lebih responsif bagi suatu perusahaan. Pada penelitian ini, dilakukan pembuatan suatu aplikasi chatbot dengan platform LINE menggunakan metode extreme programming dan startegi forward chaining yang bertujuan untuk memenuhi kebutuhan informasi bagi kolektor di PT. Indomobil Finance Indonesia (PT.IMFI) serta memberikan layanan informasi dalam waktu singkat. Hasil dari pengembangan sistem berjalan pada layanan informasi kolektor PT. IMFI menghasilkan sebuah aplikasi chatbot berbasis LINE. Hasil dari pengujian blackbox testing serta user acceptance test menghasilkan persentase keberhasilan aplikasi Chatbot Kolektor mencapai 95\%, dan persentase kegagalan aplikasi 5\%, angka tersebut menunjukkan bahwa proses pembuatan aplikasi chatbot untuk memenuhi kebutuhan layanan informasi bagi kolektor PT. Indomobil Finance Indonesia berhasil dilakukan dan seluruh fungsional berjalan sesuai dengan yang diharapkan.
\end{abstract}

Kata kunci: chatbot, line, asisten virtual, extreme programming, forward chaining.

\section{MANUFACTURING OF CHATBOT FOR COLLECTOR APPLICATION WITH EXTREME PROGRAMMING METHOD AND FORWARD CHAINING STRATEGY}

\begin{abstract}
Requests for information services at a certain point in a company are certainly a routine activity, but if requests for information services are carried out in large numbers, it will certainly be a problem. To deal with the problem of accumulating requests for information services As customer complaints, request for data, consumer demand service, new borrowers and problems like it so, virtual assistants, commonly known as chatbots, is applied. Chatbot is a virtual assistant application that is able to interact directly with every incoming message without the need to wait for the operator to reply the messages, so chatbot is a solution that can solve problems in accumulating information service requests. In addition, chatbot development is also useful for providing services to be more responsive for a company. In this study, a chatbot application was made with the LINE platform using the extreme programming method and forward chaining strategy which has the intention of meeting information needs by collectors at PT. Indomobil Finance Indonesia (PT. IMFI) And provide the information in a short time. The results of the development of the system running on the collector information service of PT. IMFI produces a LINE-based chatbot application. The results of the blackbox testing and user acceptance test resulted in a successful percentage of the Collector's Chatbot application reaching 95\%, and the percentage of application failure was 5\%, this figure shows that the process of making a chatbot application to meet the information service needs of PT. Indomobil Finance Indonesia was successfully carried out and all functions were running as expected
\end{abstract}

Keywords: chatbot, line, virtual assistant, extreme programming, forward chaining 


\section{PENDAHULUAN}

Perkembangan teknologi komunikasi dan informasi tidak hanya berpengaruh pada bidang yang berkaitan dengan komputer saja, tetapi juga berpengaruh pada bidang-bidang lain guna menunjang proses bisnis mereka agar menjadi lebih cepat, serta akurat. Salah satu bidang yang ikut terpengaruh dengan adanya perkembangan teknologi adalah customer relation, banyak perusahaan yang menerapkan pembaharuan teknologi untuk mendukung aktivitas pada bagian customer relation mereka dan juga bertujuan untuk menyelesaikan berbagai permasalahan yang dihadapi oleh customer relation mereka, salah satunya adalah permasalahan menumpuknya permintaan layanan informasi dari konsumen. Pembaharuan teknologi ini dilakukan karena customer relation adalah kunci sukses bagi suatu perusahaan, dimana customer relation adalah pintu gerbang pertama antara perusahaan dengan pelanggan, dengan perbaikan kualitas melalui penerapan teknologi terbaru pada customer relation, tentu akan membawa citra yang lebih baik bagi perusahaan tersebut.

Contoh dari perkembangan teknologi yang banyak diberlakukan pada bagian customer relation adalah penerapan aplikasi chatbot atau asisten virtual. Menurut D.Suryani \& E. L. Amalia (2017), disebutkan bahwa Chatbot merupakan aplikasi komputer yang digunakan untuk melakukan percakapan lewat tulisan. Cara kerja chatbot mirip seperti mesin penjawab telepon yang banyak digunakan pada kantor-kantor dengan fasilitas dial up. Pertanyaan yang mampu dijawab oleh aplikasi chatbot adalah pertanyaan yang bersifat umum dan sudah dipersiapkan jawabannya (Jati \& Maarif, 2018). Menurut Jati \& Maarif (2018) disebutkan bahwa Chatbot (juga dikenal sebagai talkbot, chatterbot, bot) dapat diartikan sebagai sebuah perangkat lunak yang diperuntukkan untuk mereplikasi percakapan intelek kepada satu manusia atau lebih (LINE, 2016). Sedangkan menurut literasi lain disebutkan bahwa chatbot dapat diartikan sebagai suatu program aplikasi yang dibuat secara khusus untuk memberikan respon pesan kepada manusia baik pesan tersebut berupa teks atau tulisan, suara atau audio, bahkan keduanya (Setiawan, 2018; Akhsan \& Faizah, 2017).

Chatter Bot atau Chatbot yang menggunakan machine learning atau biasa dikenal sebagai smartbot adalah chatbot yang mampu memberikan respon terhadap pesan dalam bahasa manusia melalui proses pembelajaran, tidak seperti chatbot biasa yang jawaban dari pesan yang masuk sudah ditentukan sebelumnya (Ananda, Firdha, Yusuf \& Ardiansyah, 2018).

Elisabet dan Afrianto berpendapat dalam jurnalnya yang berjudul "Rancang Bangun Aplikasi Chatbot Informasi Objek Wisata Kota Bandung dengan Pendekatan Natural Language Processing" bahwa pada dunia bisnis dan industri, pelayanan yang berupa layanan pelanggan sudah mulai menggunakan bantuan chatbot untuk memberikan respon pertanyaan dari konsumen mereka. Pelayanan menggunakan chatbot dinilai cukup efektif karena chatbot akan memberikan respon terhadap pertanyaan dari konsumen dengan sangat responsif, hal ini membuat konsumen akan memperoleh informasi yang mereka butuhkan saat itu juga (Elisabet \& Afrianto, 2015). Manfaat dari chatbot adalah untuk pelayanan informasi kepada pengguna tanpa melibatkan operator sebagai penjawab, jadi pekerjaan operator sudah di alihkan ke aplikasi chatbot (Wijaya, Sotyohadi \& Setiawan, 2015).

Umumnya, chatbot digunakan untuk membuat respon atau interaksi secara langsung kepada pengguna layanan chatbot tersebut. Hal ini dikarenakan keterbatasan sumber daya pada bagian customer relation yang biasanya tidak sebanding dengan banyaknya permintaan layanan atau pengaduan yang dihadapi oleh bagian customer relation itu sendiri. Bahkan dibanyak kasus, pelanggan merasa sulit sekali untuk dapat terhubung kepada layanan customer service suatu perusahaan karena banyaknya antrean telepon pada nomor customer service perusahaan tersebut. Hal ini tentu akan membawa citra buruk bagi perusahaan karena dinilai tidak mampu menghadapi keluhan serta permintaan layanan dari pelanggan mereka, bukan tidak mungkin jika pelanggan dari perusahaan tersebut akan berpindah menggunakan produk atau jasa lain, hal ini diakibatkan keluhan atau pemintaan layanan mereka sulit ditanggapi oleh perusahaan karena buruknya pelayanan pada bagian customer relation mereka.

Disisi lain, chatbot juga digunakan sebagai bentuk perbaikan layanan yang sudah disediakan oleh suatu perusahaan untuk meningkatkan mutu layanan mereka. Hal ini karena chatbot akan langsung merespon permintaan yang diajukan oleh user tanpa harus menunggu operator untuk membalas pesan atau telepon yang masuk. Chatbot akan langsung menampilkan jawaban informasi yang dibutuhkan oleh user dalam waktu yang sangat singkat tanpa perlu dimonitor oleh operator. Selain itu, pembuatan chatbot ditujukan untuk melakukan penghematan terhadap biaya operasional yang dikeluarkan oleh sebuah perusahaan. Oleh karena itu, chatbot banyak digunakan sebagai solusi dari berbagai permasalahan yang dihadapi oleh perusahaan khususnya pada bagian customer service. Layanan chatbot yang saat ini sudah banyak dibuat adalah layanan chatbot dengan menggunakan platform LINE.

Bedasarkan data dari hasil penelitian pada tahun 2020 yang dikerjakan oleh We Are Social yang membahas tren media sosial yang digunakan di Indonesia, sosial media terfavorit adalah sebagai 
berikut : 1) Youtube digunakan oleh 88\%, 2) Whatsapp digunakan sebanyak $84 \%$, 3) Facebook dengan jumlah $82 \%$, 4) Instagram sebanyak 79\%, 5) Twitter dengan jumlah penggunaan $56 \%$, 6) LINE dengan pengguna $56 \%, 7)$ FB Messenger sebanyak $50 \%, 8)$ LinkedIn digunakan oleh $35 \%$, 9) Pinterest sebanyak $34 \%, 10)$ WeChat dengan pengguna $29 \%$, 11) Snapchat digunakan oleh $28 \%$, 12) Skype digunakan sebanyak 25\%, 13) Tiktok dengan jumlah pengguna $25 \%, 14)$ Tumblr dengan pengguna $22 \%$, 15) Reddit sebanyak $18 \%$, dan 16) Sina Weibo dengan jumlah pengguna sebanyak $17 \%$ (Kemp, 2020; Bagus, Ari \& Widhi, 2018).

Jika dikelompokkan berdasarkan jenisnya, maka untuk jenis messenger pada urutan pertama adalah Whatsapp dengan $83 \%$ kemudian disusul LINE dengan 59\%. Namun WhatsApp belum mendukung pembuatan chatbot secara bebas, WhatsApp hanya menyediakan layanan chatbot berbayar melalui WhatsApp Bisnis mereka. Sementara, media sosial LINE memberikan akses Messaging API-nya secara bebas sejak tahun 2016 bulan September, hal ini memungkinkan para developer program untuk membuat chatbot pada aplikasi LINE (Lestari, 2016).

Chatbot berbasiskan LINE memanfaatkan teknologi restful API untuk berkomunikasi. REST atau kependekan dari Representational State Transfer adalah suatu fungsi dari protokol Hypertext Transfer Protocol atau yang lebih dikenal dengan HTTP dimana REST digunakan untuk berkomunikasi secara penuh dalam proses pertukaran representasi seperti mendapatkan suatu nilai dengan mengirimkan suatu parameter kepada suatu server REST (Junadhi \& Mardainis, 2019). Dengan adanya REST maka setiap pesan yang dikirim pengguna mampu dikenali oleh chatbot dan chatbot mampu memberikan respon atas pesan yang dikirimkan oleh pengguna.

Dalam memberikan respon, metode popular yang digunakan adalah Forward Chaining, Carolina dan Adi mengungkapkan bahwa Forward Chaining adalah suatu metode pencarian dimana dalam proses pencarian tersebut dilakukan dengan cara pelacakan secara forwarding atau ke depan. Cara tersebut memungkinkan suatu proses dimulai dengan mengumpulkan informasi yang sudah didapatkan sebelumnya kemudian digabungkan dengan suatu aturan tertentu untuk mendapatkan hasil berupa kesimpulan (Carolina \& Adi, 2019). Dengan menggunakan forward chaining, maka chatbot mampu memberikan jawaban yang sudah dipersiapkan oleh developer.

Salah satu perusahaan yang membutuhkan adanya pengembangan aplikasi chatbot adalah PT. IMFI (Indomobil Finance Indonesia). PT. IMFI adalah suatu perusahaan yang bidang bisnisnya berupa jasa pembiayaan, baik itu kendaraan bermotor, pembiayaan alat berat serta pembiayaan multiguna. Dengan didukung 240 cabang di seluruh
Indonesia, proses bisnis PT. Indomobil Finance Indonesia dijalankan selama lebih dari 26 tahun. Sebagai suatu perusahaan jasa pembiayaan yang tersebar diseluruh Indonesia, tentu PT. Indomobil Finance Indonesia menerima banyak permintaan layanan baik dari pihak internal maupun eksternal. Salah satunya adalah permintaan informasi bagi kolektor yang ada di 240 cabang PT. Indomobil Finance Indonesia. Dengan jumlah 255 orang kolektor, tentu akan menjadi sebuah masalah jika permintaan informasi dilakukan secara serentak kepada bagian Remedial and Collection (RC) PT. Indomobil Finance Indonesia sebagai pemegang informasi.

Permintaan layanan informasi oleh kolektor ini bermaksud untuk menampilkan informasi yang dibutuhkan bagi kolektor untuk menunjang pekerjaan yang dilakukan. Informasi yang dapat diakses tiap kolektor tentu bervariasi, hal ini sesuai dengan jobdesk yang telah ditentukan masingmasing cabang bagi kolektor tersebut. Namun secara umum ada 4(empat) informasi yang dapat diakses oleh kolektor, yaitu Blacklist untuk menampilkan informasi apakah pelanggan atau calon pelanggan merupakan seseorang yang masuk dalam daftar hitam oleh PT. Indomobil Finance Indonesia, Kolektor untuk menampilkan informasi rinci mengenai kendaraan yang terdaftar dalam database milik PT. Indomobil Finance Indonesia berdasarkan nomor polisi kendaraan terkait, No. Mesin untuk menampilkan informasi rinci mengenai kendaraan yang terdaftar dalam database milik PT. Indomobil Finance Indonesia berdasarkan nomor mesin kendaraan terkait, dan No. Rangka untuk menampilkan informasi rinci mengenai kendaraan yang terdaftar dalam database milik PT. Indomobil Finance Indonesia berdasarkan nomor rangka kendaraan terkait.

Saat ini PT. Indomobil Finance Indonesia menyediakan layanan SMSCenter untuk melayani permintaan informasi bagi kolektor, cara kerjanya adalah dengan mengirimkan sms ke nomor yang disediakan kemudian nomor tersebut akan mengirimkan pesan balasan berupa informasi yang diminta oleh kolektor. Namun cara ini dirasa kurang efektif karena bergantung pada kartu sim atau simcard yang di pergunakan, jika simcard atau kartu sim yang di pergunakan mengalami gangguan, maka layanan informasi kepada kolektor ikut terputus tanpa adanya layanan lain yang serupa. Sehingga jika gangguan tersebut terjadi dalam waktu yang cukup lama, kolektor juga tidak dapat menerima informasi apapun, hal ini tentu membuat pekerjaan dari kolektor tidak dapat dilakukan secara maksimal. Selain itu, beban biaya yang dikeluarkan oleh PT. Indomobil Finance Indonesia untuk membayar tagihan biaya sms tiap bulan terbilang cukup besar karena harus menyediakan layanan bagi 240 cabang dengan waktu layanan setiap hari tanpa ada batasan waktu. 
Pada penelitian terdahulu yang telah membahas tentang pembaruan teknologi informasi untuk mengatasi masalah permintaan pelayanan informasi, seperti pada penelitian milik Ananda, Firdha, Yusuf, dan Ardiansyah tentang MILKI BOT (Ananda, Firdha, Yusuf \& Ardiansyah, 2018). Penelitian yang dikerjakan telah berhasil menyelesaikan permasalahan yang dihadapi oleh customer service pada UKM Misnu. Selain itu penelitian sejenis juga dikerjakan oleh Junadhi, dan Mardainis tentang LINE Chatbot Informasi Cuaca Wilayah Indonesia (Wijaya, Sotyohadi \& Setiawan, 2015), juga telah berhasil menyelesaikan permasalahan permintaan informasi yang diangkat pada penelitian tersebut.

Berdasarkan penelitian tersebut, maka untuk menyelesaikan permasalahan yang dialami oleh PT.Indomobil Finance Indonesia, dalam penelitian ini dibutuhkan sebuah layanan chatbot dengan platform LINE untuk memenuhi permintaan layanan informasi bagi kolektor PT. Indomobil Finance Inonesia dengan metode Extreme Programming dan Forward Chaining, serta digunakan bahasa pemrograman vb.net sebagai media untuk membuat web service, serta memanfaatkan Messaging API LINE untuk menghubungkan web service yang dibuat dengan LINE Official Account yang disediakan.

\section{METODE PENELITIAN}

Proses pembuatan aplikasi chatbot yang dikerjakan pada penelitian ini secara garis besar menggunakan 2 metode, metode tersebut yaitu metode Extreme Programming serta Forward Chaining. Pada proses pengerjaan pembuatan aplikasi ini dilakukan 4 tahapan sesuai dengan tahapan yang ada pada metode Extreme Programming (Benedictus, Wowor \& Sambul, 2017), tahapan tersebut adalah:

\subsection{Tahap Planning}

Tahap Planning ini terdiri dari pengumpulan data yang terdiri dari manual penggunaan aplikasi dari program yang saat ini sudah berjalan di PT. Indomobil Finance Indonesia, juga kebutuhan user yang didapatkan dengan wawancara langsung kepada user dari departemen Remedial and Collection dengan menanyakan apa saja yang perlu dikembangkan dan dihilangkan dari program yang saat ini sudah berjalan di PT. Indomobil Finance Indonesia, selain itu, pada tahap ini juga peneliti mempelajari alur program yang sudah tersedia dengan cara melakukan proses debug pada sistem yang ada untuk memahami proses dan alur kerja yang saat ini sudah berjalan.

\subsection{Tahap Design}

Tahap Design pada penelitian ini adalah dengan melakukan perancangan tampilan serta perancangan input pada aplikasi

\subsection{Tahap Coding}

Pada tahap Coding, kegiatan yang dilakukan terdiri dari pembuatan web service, penentuan akses database sebagai knowledge base, melakukan konfigurasi webhook, serta pembuatan logic program.

\subsection{Tahap Testing}

Tahap testing dilakukan dengan memasukkan input pada $\underline{\text { chatbot. }}$.

Strategi forward chaining diterapkan untuk menentukan alur percakapan yang akan diterapkan

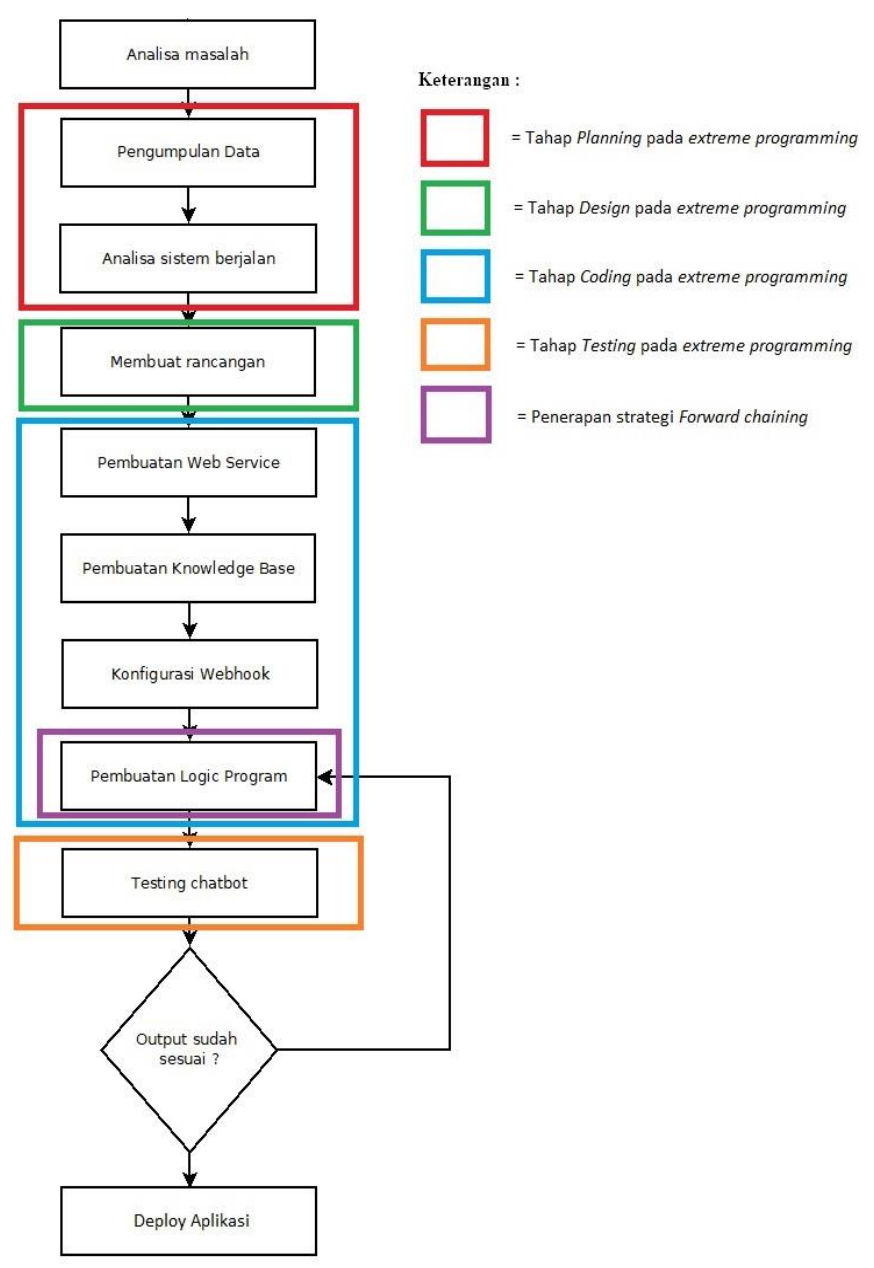

Gambar 1. Tahapan Penelitian

Gambar 1 menunjukkan detail dari masingmasing proses dalam metode extreme programming, yaitu garis berwarna merah untuk menunjukkan tahap Planning, garis berwarna hijau untuk menujukkan tahap Design, garis berwarna biru untuk 
menujukkan tahap Coding, dan garis berwarna oranye untuk menunjukkan proses Testing.

Dari gambar 1 juga terlihat strategi forward chaining digunakan sebagai strategi pada saat proses pembuatan logic program yang ditandai oleh garis berwarna ungu. Strategi forward chaining diterapkan pada tahap coding untuk menentukan input apa yang akan direspon benar oleh chatbot, selain itu forward chaining juga mampu menentukan bagaimana alur jika input yang diberikan oleh pengguna tidak sesuai dengan kata kunci yang sudah dibuat oleh pengembang.

\section{HASIL DAN PEMBAHASAN}

\subsection{Hasil Penelitian}

Untuk mendapatkan jawaban sejauh mana aplikasi yang dikembangkan mampu menyelesaikan permasalahan, maka dilakukan perbandingan antara sistem yang saat ini berjalan di PT. Indomobil Finance Indonesia, yaitu aplikasi SMSCenter dengan aplikasi Chatbot Kolektor. Berikut tabel 1 dan tabel 2 menunjukkan hasil perbandingan aplikasi SMSCenter dengan Chatbot Kolektor.

Tabel 1. Hasil Perbandingan Aplikasi Berjalan Dengan Aplikasi Yang Dibangun Pada Penelitian Ini

\begin{tabular}{llll}
\hline No & Permasalahan & $\begin{array}{l}\text { Aplikasi } \\
\text { Berjalan }\end{array}$ & Chatbot Kolektor \\
\hline 1 & $\begin{array}{l}\text { Bergantung pada } \\
\text { kartu SIM }\end{array}$ & $\begin{array}{l}\text { Ya, secara } \\
\text { menyeluruh }\end{array}$ & $\begin{array}{l}\text { Ya, sebagian (hanya } \\
\text { untuk mengirim SMS } \\
\text { OTP diawal } \\
\text { pendaftaran) }\end{array}$ \\
\hline 2 & $\begin{array}{l}\text { Bergantung pada } \\
\text { internet }\end{array}$ & Tidak & Ya \\
\hline 3 & $\begin{array}{l}\text { Memerlukan biaya } \\
\text { per pesan }\end{array}$ & Ya & Tidak \\
\hline 4 & $\begin{array}{l}\text { Gangguan } \\
\text { pelayanan pada 3 } \\
\text { bulan terakhir }\end{array}$ & Ya & Tidak \\
\hline 5 & $\begin{array}{l}\text { Maintenance Ketika Perlu hard reset } \\
\text { gangguan }\end{array}$ & modem gsm & $\begin{array}{l}\text { Hanya melakukan } \\
\text { pengecekan apakah } \\
\text { webhook dapat } \\
\text { diverifikasi. }\end{array}$ \\
& & & \\
\hline & & &
\end{tabular}

Berdasarkan pada Tabel 1, Aplikasi yang saat ini berjalan di PT. Indomobil Finance Indonesia yaitu aplikasi SMSCenter, mempunyai ketergantungan pada kartu sim, hal ini dikarenakan semua layanan yang berjalan pada aplikasi SMSCenter berupa pesan masuk dan pesan keluar diproses menggunakan pesan singkat atau lebih dikenal dengan SMS. Hal ini membuat aplikasi SMSCenter bergantung secara menyeluruh pada kartu sim, sedangkan pada aplikasi yang dikembangkan di penelitian ini yaitu Chatbot Kolektor, penggunaan kartu sim hanya bergantung sebagian, yaitu ketika chatbot kolektor perlu mengirimkan pesan One Time Password atau yang lebih dikenal dengan OTP, OTP ini merupakan sebuah pesan singkat yang berisikan sebuah deret angka yang berfungsi sebagai Password, password ini hanya akan berlaku 1 kali saja ketika dimasukkan oleh pengguna di sistem chatbot kolektor, pengiriman pesan OTP ini ditujukan untuk validasi nomor yang digunakan oleh kolektor ketika mendaftar di layanan aplikasi Chatbot Kolektor.

Aplikasi SMSCenter tidak bergantung pada internet sama sekali, hal ini karena service yang berjalan sepenuhnya menggunakan komunikasi fisik dari modem gsm ke aplikasi SMSCenter. Sedangkan Chatbot Kolektor, bergantung sepenuhnya pada internet, hal ini dikarenakan pertukaran informasi yang dilakukan berjalan pada platform messaging application LINE yang membutuhkan internet untuk beroperasi. Selain itu, komunikasi antara Messaging API LINE dengan webhook handler di sisi internal juga membutuhkan akses internet, sehingga Chatbot Kolektor bergantung sepenuhnya pada akses internet. Pada bagian pembiayaan, aplikasi SMSCenter membutuhkan biaya untuk tiap pesan yang dikirimkan sebagai respon dari permintaan informasi yang dilakukan oleh kolektor, besaran biaya yang ditagihkan tergantung pada jenis kartu sim yang digunakan, pada aplikasi SMSCenter sendiri kartu sim yang digunakan adalah kartu Halo dengan tarif per pesannya adalah Rp. 350,-. Sedangkan aplikasi Chatbot Kolektor tidak membutuhkan biaya untuk pertukaran pesan yang terjadi, hal ini dikarenakan aplikasi Chatbot Kolektor berjalan diatas platform LINE yang tidak membebankan biaya perpesanan yang dilakukan (Free Messaging Application) sehingga sebanyak apapun pertukaran pesan yang terjadi pada aplikasi Chatbot Kolektor tidak akan memengaruhi biaya operasional yang perlu dikeluarkan oleh PT. Indomobil Finance Indonesia.

Jika dilihat pada track record 3 bulan terakhir, aplikasi SMSCenter mengalami beberapa kali gangguan pelayanan, terhitung sejak Desember 2019 aplikasi SMSCenter mengalami 6 kali gangguan yang menyebabkan seluruh layanan tidak berfungsi, yaitu pada tanggal 2 Januari 2020, 3 Januari 2020, 4 Januari 2020, dan 5 Januari 2020, serta tanggal 1 dan 2 Februari 2020. Gangguan ini berasal dari kondisi sinyal pada kartu sim yang tidak stabil sehingga menyebabkan modem GSM mengalami system failure sehingga modem tidak dapat berjalan dengan semestinya dan sistem pelayanan lumpuh hingga modem direstart secara manual. Sedangkan track record 3 bulan terakhir pada aplikasi Chatbot Kolektor, pelayanan berjalan penuh selama $1 \times 24$ jam perhari tanpa mengalami adanya gangguan pelayanan.

Dalam hal penanganan masalah jika terjadi gangguan, arsitektur aplikasi SMSCenter yang mengandalkan fisik menyebabkan jika sistem mengalami masalah, maka diperlukan pemeriksaan fisik terkait sistem aplikasi SMSCenter. Permasalahan yang terjadi selama ini disebabkan oleh kondisi simcard yang hang, ataupun modem gsm yang mengalami kondisi hang. Untuk bisa menyelesaikan permasalahan tersebut, maka tim 
development perlu datang ke ruang server dan mengatur ulang posisi simcard dan menonaktifkan modem gsm sementara untuk kemudian dinyalakan kembali. Sementara, pada aplikasi Chatbot Kolektor, jika terjadi permasalahan pada layanan, maka yang perlu dilakukan adalah melakukan pemeriksaan ketersediaan webhook yang disetting pada halaman LINE Developer untuk memastikan bahwa Messaging API LINE mampu berkomunikasi dengan sistem internal yang dimiliki. Jika webhook tidak dapat diverifikasi, maka hal yang perlu dilakukan adalah memeriksa pengaturan API messaging LINE pada webhook yang dimiliki.

Tabel 2. Hasil Perbandingan Response Time Antara Aplikasi Berjalan Dengan Aplikasi Yang Dibangun Pada Penelitian Ini

\begin{tabular}{llc|c}
\hline \multirow{2}{*}{ No } & Tugas & \multicolumn{2}{c}{ Response Time(detik) } \\
\cline { 3 - 4 } & SMSCenter & $\begin{array}{l}\text { Chatbot } \\
\text { Kolektor }\end{array}$ \\
\hline 1 & Modul Kolektor & 26.10 & 1.97 \\
\hline 2 & Modul Blacklist & 26.35 & 1.21 \\
\hline 3 & Modul Mesin & 19.02 & 3.75 \\
\hline 4 & Modul Rangka & 25.54 & 6.76 \\
\hline Jumlah & 97.01 & 13.69 \\
\hline Rata-rata waktu tes & 24.25 & 3.42 \\
\hline
\end{tabular}

Hasil diatas merupakan hasil response time yang didapatkan dari proses perhitungan secara manual menggunakan stopwatch yang difungsikan untuk menunggu hingga system mengirimkan balasan dari pesan yang masuk, dan berdasarkan hasil perbandingan response time yang ditunjukkan pada tabel 2, maka didapatkan data bahwa pada aplikasi SMSCenter waktu yang diperlukan untuk menampilkan respon pada modul kolektor adalah 26.10 detik, kemudian pada modul blacklist aplikasi SMSCenter membutuhkan waktu 26.35 detik untuk menampilkan respon. Pada modul mesin, aplikasi SMSCenter membutuhkan waktu 19.02 detik, dan pada modul rangka waktu yang diperlukan oleh aplikasi SMSCenter adalah 25.54.

Sementara untuk aplikasi yang dibangun pada penelitian ini yaitu Aplikasi Chatbot Kolektor membutuhkan waktu 1.97 detik untuk menampilkan respon pada modul kolektor. Untuk modul blacklist, aplikasi Chatbot Kolektor memerlukan waktu 1.21 detik untuk membalas respon. Untuk modul mesin, waktu yang dibutuhkan adalah 3.75 detik, dan pada modul rangka, waktu yang dibutuhkan aplikasi Chatbot Kolektor adalah 6.76 detik.

Dari perbandingan tersebut, maka rata-rata respon yang diperlukan oleh aplikasi SMSCenter untuk menampilkan respon adalah 24.25 detik, sementara pada aplikasi Chatbot Kolektor waktu rata-rata yang dibutuhkan untuk menampilkan respon adalah 3.42 detik, sehingga dapat disimpulkan bahwa aplikasi Chatbot Kolektor mampu menampilkan respon balasan dari pengguna lebih cepat dibandingkan dengan aplikasi yang saat ini berjalan yaitu SMSCenter.
Berdasarkan hasil yang terdapat pada tabel 1 dan tabel 2, maka dapat disimpulkan bahwa aplikasi Chatbot Kolektor mampu menjadi solusi untuk menghemat biaya operasional yang dikeluarkan oleh PT. Indomobil Finance Indonesia, serta menjadi solusi bagi permasalahan ketersediaan layanan informasi bagi kolektor PT. Indomobil Finance Indonesia.

\subsection{PEMBAHASAN}

\subsubsection{Pengumpulan Data (Tahap Planning Pada Extreme Programming)}

Tahapan penelitian yang dimulai dengan tahapan planning, pada tahap planning ini peneliti mengumpulkan kebutuhan yang diperlukan untuk membangun aplikasi Chatbot Kolektor. Pada penelitian ini pengumpulan data dilakukan secara observasi. Teknik observasi ini dilakukan dengan melakukan wawancara langsung pada divisi Remedial and Collection ( $R C$ ) selaku pemegang data, selain wawancara observasi juga dilakukan dengan mempelajari aplikasi yang saat ini berjalan di PT. Indomobil Finance Indonesia, yaitu SMSCenter. Pengumpulan data ini dilakukan untuk kebutuhan perancangan dan testing pada penelitian ini. Data yang diproses oleh peneliti dalam penelitian ini berupa data primer yaitu data kolektor dan data kendaraan yang terdaftar di PT. Indomobil Finance Indonesia.

Adapun pengumpulan data yang dikerjakan oleh peneliti dalam penelitian ini adalah dengan teknik wawancara, teknik wawancara ini dilakukan melalui internal meeting yang dilakukan di ruang meeting PT. Indomobil Finance Indonesia. Internal Meeting untuk persiapan pembuatan Chatbot Kolektor ini dihadiri oleh Ibu Nasya (Staff) dan Bapak Hengky (Kepala Departemen) dari divisi Remedial and Collection ( $R C$ ) selaku pemegang data, dan Muhamad Sidik (Staff) serta Kresnoadi (Supervisor) dari divisi Information and Technology (IT) selaku pengembang aplikasi. Hasil dari internal meeting ini adalah kebutuhan user yakni sebuah aplikasi yang menyerupai aplikasi SMSCenter namun tidak bergantung pada simcard, hal ini dikarenakan seringnya terjadi masalah aplikasi SMSCenter karena adanya gangguan sinyal pada simcard maupun kondisi modem hang. Selain itu, kebutuhan ini juga bertujuan untuk melakukan penghematan pengeluaran biaya operasional tanpa mengurangi pelayanan yang ada.

Selain melalui wawancara kepada pemegang data, pengumpulan data juga dilakukan dengan melakukan observasi pada aplikasi berjalan, yaitu aplikasi SMSCenter. Tujuan dari observasi ini adalah memahami alur kerja dari aplikasi SMSCenter sebagai dasar pembuatan aplikasi Chatbot Kolektor bagi PT. Indomobil Finance Indonesia. 


\subsubsection{Analisa Sistem Berjalan (Tahap Planning Pada Extreme Programming)}

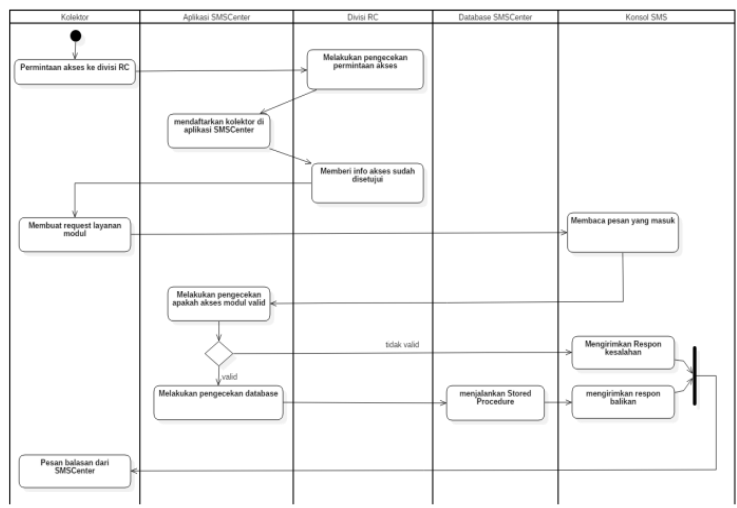

Gambar 2. Alur dari Sistem yang saat ini berjalan

Berdasarkan gambar 2, kolektor yang belum memiliki akses akan mengajukan form permintaan akses kepada divisi $R C$ atau Remedial and Collection. Setelah mendapatkan form pengajuan akses, maka divisi $R C$ akan melakukan pengecekan terlebih dahulu, jika memang data yang dikirimkan valid, maka divisi $R C$ akan membuatkan akses bagi kolektor yang bersangkutan dan akan mengirimkan info bahwa kolektor tersebut sudah bisa melakukan request info by sms. Jika sudah memiliki akses, user mampu meminta informasi mengenai kendaraan dan calon kreditur melalui modul yang didaftarkan oleh divisi $R C$. Pesan yang masuk dari nomor kolektor akan dibaca oleh konsol sms untuk kemudian dicek valid atau tidaknya request di aplikasi SMSCenter.

Jika request tidak valid, maka aplikasi SMSCenter akan mengirimkan balasan berupa respon kesalahan (exception). Jika request valid, maka request akan diteruskan ke database untuk kemudian diolah dalam bentuk stored procedure dan hasil dari stored procedure akan dikirimkan kembali melalui konsol sms untuk diteruskan ke kolektor.

\subsubsection{Membuat Rancangan (Tahap Design pada Extreme Programming)}

Proses design digunakan untuk memberikan gambaran awal tentang aplikasi chatbot yang akan dibuat, rancangan dibuat secara sederhana dan langsung diberikan kepada pihak pemegang data (divisi Remedial and Collection). Jika rancangan disetujui maka pembangunan aplikasi chatbot akan mengacu pada rancangan yang sudah disepakati pada tahap ini. Rancangan tampilan aplikasi Chatbot Kolektor pada penelitian ini dibangun dengan menggunakan aplikasi Balsamiq mockup. Contoh rancangan yang dilakukan pada tahap design pada penelitian ini dapat dilihat pada gambar 3 .

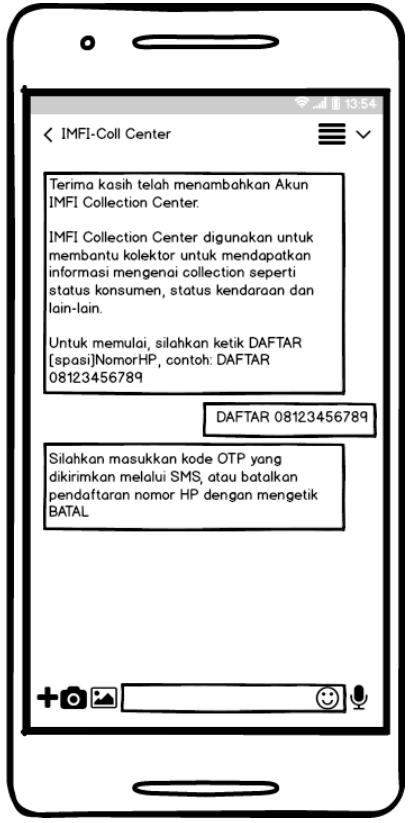

Gambar 3. Rancangan Tampilan Aplikasi Chatbot Kolektor

\subsubsection{Tahap Pembuatan Coding \\ 3.2.4.1 Pembuatan web service (Tahap Coding pada Extreme Programming)}

Pembuatan web service bertujuan untuk membuat suatu wadah sebagai pintu gerbang komunikasi antara chatbot dengan knowledge base yang ada di sistem internal di PT. Indomobil Finance Indonesia, pembuatan web service ini menggunakan bantuan tools visual studio atau VS2010 dan bahasa pemrograman menggunakan visual basic atau VB.Net 2010.

\subsubsection{Pembuatan Knowledge Base (Tahap Coding pada Extreme Programming)}

Pembuatan knowledge base merupakan bagian inti dari pembuatan sebuah chatbot, karena dengan knowledge base ini-lah chatbot akan mampu memberikan respon informasi yang dibutuhkan oleh pengguna. Pembuatan knowledge base pada penelitian ini memanfaatkan database yang sudah ada, dengan menjalankan store procedure yang sudah disiapkan pada database maka hasil dari query store procedure tersebut yang kemudian akan diteruskan menjadi respon dari masukkan yang diinput oleh pengguna.

\subsubsection{Konfigurasi Webhook (Tahap Coding pada Extreme Programming)}

Konfigurasi webhook pada penelitian ini dilakukan untuk menghubungkan web service dengan layanan API LINE. Layanan API (Application Programming Interface) LINE adalah sebuah layanan yang memungkinkan sebuah sistem dapat berkomunikasi dengan platform milik LINE 
sehingga developer program mampu membangun suatu aplikasi berbasis LINE yang dapat berkomunikasi langsung dengan Fitur yang terdapat pada LINE. Untuk bisa melakukan konfigurasi, maka dibutuhkan akun LINE developer, didalam akun LINE developer ini juga peneliti melakukan konfigurasi lain untuk chatbot, misal ikon chatbot, nama chatbot, dan lain-lain. Salah satu konfigurasi yang dilakukan pada penelitian ini adalah memasukkan alamat URL webhook, kegiatan ini dapat dilihat pada gambar 4 .

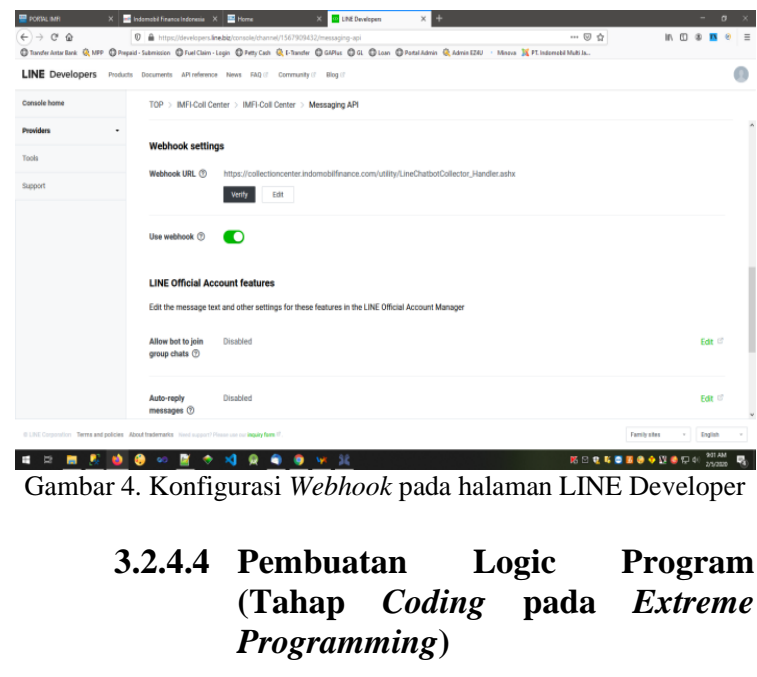

Pembuatan logic program dilakukan pada web service yang sudah disiapkan sebelumnya, pada proses pembuatan logic program ini strategi forward chaining diterapkan. Dengan menerapkan strategi jika-maka yang ada pada forward chaining, seluruh input yang akan dimasukan oleh user untuk berinteraksi dengan chatbot akan ditentukan pada tahap ini, respon yang sudah disiapkan pada knowledge base juga akan diatur sebagai respon dalam tahap ini.

\subsubsection{Strategi Forward Chaining}

Strategi forward chaining pada penelitian ini digunakan untuk menentukan alur atau arah interaksi yang dilakukan oleh chatbot dengan pengguna. Setelah user/client menambahkan Chatbot Kolektor sebagai teman maka bot akan menampilkan pesan pembuka. Kemudian user akan melakukan input kata kunci yang nantinya akan diproses oleh chatbot, apabila kata kunci sesuai maka akan langsung direspon oleh chatbot, apabila tidak sesuai maka chatbot akan menampilkan "default feedback" dengan pesan atau kata yang diinginkan, semisal "saya tidak mengerti maksud anda?", "mohon masukkan kata kunci yang sesuai". Setelah ditampilkan hasil dari masukan tersebut, user bisa memasukkan kata kunci kembali atau mengakhiri percakapan.

Gambar 5 menunjukkan alur aplikasi Chatbot Kolektor dengan menerapkan aturan "jika-maka" yang terdapat pada metode forward chaining.
Aturan "jika-maka" dalam forward chaining ini memungkinan aplikasi chatbot untuk menentukan bagaimana respon yang akan diberikan jika input yang dilakukan oleh user adalah input yang sesuai atau tidak sesuai. Dengan forward chaining, aplikasi Chatbot Kolektor juga mampu menentukan default feedback yang akan diberikan jika keyword pesan yang dimasukkan oleh user tidak dikenali.

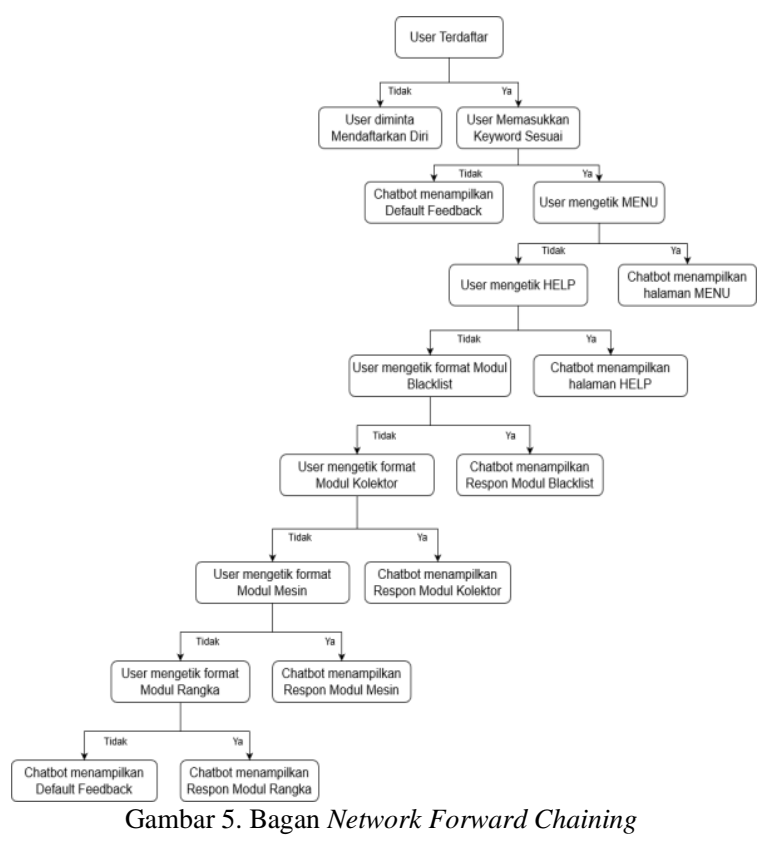

\subsubsection{Tahap Testing Aplikasi (Tahap Testing pada metode Extreme Programming)}

\subsubsection{Blackbox Testing}

a) Analisa kebutuhan dan spesifikasi.

Perencanaan pengujian perangkat lunak dengan blackbox testing dilakukan dengan melakukan analisa kebutuhan dan spesifikasi pengujian yang diperlukan. Terdapat beberapa kebutuhan yang diperlukan pada penelitian ini untuk membuat blackbox testing yaitu aplikasi yang akan dilakukan pengujian, sistem operasi yang digunakan untuk menjalankan pengujian, dan basis data yang digunakan dalam pengujian. Tabel 3 menunjukkan hasil dari analisa kebutuhan dan spesifikasi yang digunakan pada pengujian perangkat lunak dengan menggunakan blackbox testing.

Tabel 3. Analisa Kebutuhan Blackbox Testing

\begin{tabular}{lll}
\hline No & Kebutuhan & Keterangan \\
\hline 1 & $\begin{array}{l}\text { Aplikasi yang dilakukan } \\
\text { pengujian }\end{array}$ & $\begin{array}{l}\text { Aplikasi yang diuji adalah } \\
\text { aplikasi Chatbot Kolektor } \\
\text { yang dibangun pada } \\
\text { penelitian ini. }\end{array}$ \\
\hline 2 & Sistem operasi & Windows 10 64 bit \\
\hline 3 & Basis data & SQLServer 2012 \\
\hline
\end{tabular}


b) Pemilihan Input.

Tahapan selanjutnya dilakukan pemilihan input untuk dilakukan pengujian. Pemilihan input ini bertujuan untuk menentukan input yang akan dimasukkan dalam pengujian perangkat lunak secara blackbox testing. Adapun pemilihan input yang dilakukan pada penelitian ini adalah input sesuai dengan keyword yang sudah ditentukan, dan input yang tidak sesuai dengan keyword yang sudah ditentukan.

c) Pemilihan Output.

Proses pemilihan output dilakukan untuk memberikan jawaban dari tiap pesan yang masuk serta alur dari proses yang akan berjalan pada halaman pesan Chatbot Kolektor.

d) Pengujian

Setelah dilakukan pemilihan input dan pemilihan output, maka langkah berikutnya adalah melakukan pengujian terhadap aplikasi Chatbot Kolektor. Hasil dari pengujian blackbox yang dilakukan dapat dilihat pada Tabel 4 .

e) Review Hasil

Berdasarkan tabel 4 yang berisi hasil pengujian aplikasi dengan menggunakan blackbox testing, didapatkan kesimpulan bahwa seluruh fungsi yang berjalan pada aplikasi Chatbot Kolektor sudah berjalan sesuai dengan fungsinya dan respon yang diharapkan telah ditampilkan dengan sesuai.

Tabel 4. Hasil Pengujian Blackbox Testing

\begin{tabular}{|c|c|c|c|c|}
\hline \multirow[t]{2}{*}{$\overline{\text { No }}$} & \multirow{2}{*}{$\begin{array}{l}\text { Langkah } \\
\text { Skenario }\end{array}$} & \multicolumn{2}{|c|}{ Hasil Yang Hasil } & \multirow[t]{2}{*}{ Hasil Akhir } \\
\hline & & Diharapkan & Aktual & \\
\hline 1 & $\begin{array}{l}\text { User input BLK K } \\
140302500698000 \\
1 \text { (Data Tersedia) }\end{array}$ & $\begin{array}{l}\text { Chatbot } \\
\text { merespon data } \\
\text { blacklist }\end{array}$ & $\begin{array}{l}\text { Chatbot } \\
\text { merespon } \\
\text { data } \\
\text { blacklist }\end{array}$ & $\begin{array}{l}\text { Pengujian } \\
\text { Sukses }\end{array}$ \\
\hline 2 & $\begin{array}{l}\text { User input Blk k } \\
123456789012345 \\
6 \text { (NIK ketik asal) }\end{array}$ & $\begin{array}{l}\text { Chatbot } \\
\text { merespon data } \\
\text { NIK tidak ada }\end{array}$ & $\begin{array}{l}\text { Chatbot } \\
\text { merespon } \\
\text { data OK }\end{array}$ & $\begin{array}{l}\text { Pengujian } \\
\text { Gagal }\end{array}$ \\
\hline 3 & $\begin{array}{l}\text { User input KOL } \\
\text { K6408084504670 } \\
\text { 002 (Data Tidak } \\
\text { Tersedia) }\end{array}$ & $\begin{array}{l}\text { Chatbot } \\
\text { merespon } \\
\text { format pesan } \\
\text { error }\end{array}$ & $\begin{array}{l}\text { Chatbot } \\
\text { merespon } \\
\text { format } \\
\text { sms salah }\end{array}$ & $\begin{array}{l}\text { Pengujian } \\
\text { Gagal }\end{array}$ \\
\hline 4 & $\begin{array}{l}\text { User input KOL } \\
\text { b1234abc (Data } \\
\text { Tidak Tersedia) }\end{array}$ & $\begin{array}{l}\text { Chatbot } \\
\text { merespon data } \\
\text { tidak tersedia }\end{array}$ & $\begin{array}{l}\text { Chatbot } \\
\text { merespon } \\
\text { data tidak } \\
\text { tersedia }\end{array}$ & $\begin{array}{l}\text { Pengujian } \\
\text { Sukses }\end{array}$ \\
\hline 5 & $\begin{array}{l}\text { User input MSN } \\
\text { 2SV223155 (Data } \\
\text { Tersedia) }\end{array}$ & $\begin{array}{l}\text { Chatbot } \\
\text { merespon data } \\
\text { detail mesin }\end{array}$ & $\begin{array}{l}\text { Chatbot } \\
\text { merespon } \\
\text { data detail } \\
\text { mesin }\end{array}$ & $\begin{array}{l}\text { Pengujian } \\
\text { Sukses }\end{array}$ \\
\hline 6 & $\begin{array}{l}\text { User input MSN } \\
\text { jfh123456 (Data } \\
\text { Tidak Tersedia) }\end{array}$ & $\begin{array}{l}\text { Chatbot } \\
\text { merespon data } \\
\text { tidak tersedia }\end{array}$ & $\begin{array}{l}\text { Chatbot } \\
\text { merespon } \\
\text { data tidak } \\
\text { tersedia }\end{array}$ & $\begin{array}{l}\text { Pengujian } \\
\text { Sukses }\end{array}$ \\
\hline 7 & $\begin{array}{l}\text { User input RNK } \\
\text { mh328d204ak255 } \\
974 \text { (Data } \\
\text { Tersedia) }\end{array}$ & $\begin{array}{l}\text { Chatbot } \\
\text { merespon data } \\
\text { detail rangka }\end{array}$ & $\begin{array}{l}\text { Chatbot } \\
\text { merespon } \\
\text { data detail } \\
\text { rangka }\end{array}$ & $\begin{array}{l}\text { Pengujian } \\
\text { Sukses }\end{array}$ \\
\hline 8 & $\begin{array}{l}\text { User input RNK } \\
123456789 \text { (Data } \\
\text { Tidak Tersedia) }\end{array}$ & $\begin{array}{l}\text { Chatbot } \\
\text { merespon data } \\
\text { tidak tersedia }\end{array}$ & $\begin{array}{l}\text { Chatbot } \\
\text { merespon } \\
\text { data tidak } \\
\text { tersedia }\end{array}$ & $\begin{array}{l}\text { Pengujian } \\
\text { Sukses }\end{array}$ \\
\hline
\end{tabular}

\begin{tabular}{|c|c|c|c|c|}
\hline \multirow[t]{2}{*}{ No } & \multirow{2}{*}{$\begin{array}{l}\text { Langkah } \\
\text { Skenario }\end{array}$} & \multicolumn{2}{|c|}{ Hasil $\quad$ Yang Hasil } & \multirow[t]{2}{*}{ Hasil Akhir } \\
\hline & & Diharapkan & Aktual & \\
\hline 9 & $\begin{array}{l}\text { User input MENU } \\
\text { (Keyword sesuai) }\end{array}$ & $\begin{array}{l}\text { Chatbot } \\
\text { menampilkan } \\
\text { pesan MENU }\end{array}$ & $\begin{array}{l}\text { Chatbot } \\
\text { menampil } \\
\text { kan pesan } \\
\text { MENU }\end{array}$ & $\begin{array}{l}\text { Pengujian } \\
\text { Sukses }\end{array}$ \\
\hline$\overline{10}$ & $\begin{array}{l}\text { User input HELP } \\
\text { (Keyword sesuai) }\end{array}$ & $\begin{array}{l}\text { Chatbot } \\
\text { menampilkan } \\
\text { pesan HELP }\end{array}$ & $\begin{array}{l}\text { Chatbot } \\
\text { menampil } \\
\text { kan pesan } \\
\text { HELP }\end{array}$ & $\begin{array}{l}\text { Pengujian } \\
\text { Sukses }\end{array}$ \\
\hline$\overline{11}$ & $\begin{array}{l}\text { User input HAI } \\
\text { (Keyword tidak } \\
\text { sesuai) }\end{array}$ & $\begin{array}{l}\text { Chatbot } \\
\text { menampilkan } \\
\text { pesan MENU }\end{array}$ & $\begin{array}{l}\text { Chatbot } \\
\text { menampil } \\
\text { kan pesan } \\
\text { MENU }\end{array}$ & $\begin{array}{l}\text { Pengujian } \\
\text { Sukses }\end{array}$ \\
\hline$\overline{12}$ & $\begin{array}{l}\text { User input } \\
\text { ASDASD } \\
\text { (Keyword tidak } \\
\text { sesuai) }\end{array}$ & $\begin{array}{l}\text { Chatbot } \\
\text { menampilkan } \\
\text { pesan MENU }\end{array}$ & $\begin{array}{l}\text { Chatbot } \\
\text { menampil } \\
\text { kan pesan } \\
\text { MENU }\end{array}$ & $\begin{array}{l}\text { Pengujian } \\
\text { Sukses }\end{array}$ \\
\hline
\end{tabular}

\subsubsection{User Acceptance Test}

UAT atau User Acceptance Test dilakukan untuk mendapatkan konfirmasi user bahwa aplikasi yang dibangun sudah sesuai dengan apa yang user inginkan. Pada penelitian ini, dibuat sebuah Form UAT untuk diberikan kepada Ibu Nasya selaku staff pada divisi Remedial and Collection dan Bapak Hengky selaku Kepala Departemen Remedial and Collection, serta kepada 98 partisipan lain yang terdiri dari Staff, Coordinator, dan Supervisor yang ada di Departemen Remedial and Collection sehingga total partisipan untuk UAT dalam penelitian ini adalah 100 responden untuk melakukan pemeriksaan tiap fungsi yang ada pada Chatbot Kolektor.

Dari 100 data yang dilakukan pengujian, terdapat 5 data yang mengalami gagal uji karena respon yang diberikan tidak sesuai dengan yang diharapkan, gagal uji tersebut dikarenakan terdapat format balasan tidak sesuai dengan yang seharusnya pada 4 pesan yang dikirimkan, selain itu terdapat juga gagal uji pada 1 pesan masuk ketika data yang dimasukkan adalah data nik berisi angka acak, chatbot merespon dengan pesan OK, seharusnya terdapat validasi terlebih dahulu apakah data nik yang dimasukkan sesuai dengan format nik yang sesuai.

Berikut perhitungan persentase keberhasilan Aplikasi Chatbot Kolektor berdasarkan pengujian pada 100 data.

Persentase Keberhasilan $=\frac{\text { Data Berhasil }}{\text { fumlah Data }} \times 100 \%$, Maka

Persentase Keberhasilan $=\frac{(100-5)}{100} \times 100 \%=\frac{95}{100} \times 100 \%=95 \%$

Persentase Kegagalan $=\frac{\text { Data Gagal }}{\text { Jumlah Data }} x 100 \%$, Maka

Persentase Kegagalan $=\frac{5}{100} x 100 \%=5 \%$

\section{KESIMPULAN}

Menurut data yang didapatkan dari proses penelitian ini, penulis menyimpulkan bahwa pengembangan aplikasi chatbot kolektor pada PT. 
Indomobil Finance Indonesia dapat dilakukan dengan menggunakan metode extreme programming dan strategi forward chaining. Proses pengembangan aplikasi chatbot dikembangkan dari aplikasi SMSCenter yang saat ini sudah berjalan di PT. Indomobil Finance Indonesia untuk memenuhi layanan informasi bagi kolektor. Berdasarkan hasil analisa dan pengujian aplikasi dengan blackbox testing serta user acceptance test, hasil pengujian menunjukkan persentase keberhasilan aplikasi Chatbot Kolektor mencapai $95 \%$ dan persentase kegagalan aplikasi adalah 5\%. Dari angka tersebut, maka dapat disimpulkan aplikasi Chatbot Kolektor telah berhasil dibangun dan mampu menangani permintaan layanan informasi bagi kolektor di PT. Indomobil Finance Indonesia serta menunjukkan seluruh fungsional berjalan sesuai dengan yang diharapkan. Berdasarkan data analisa perbandingan antara aplikasi SMSCenter yang saat ini berjalan dengan aplikasi Chatbot Kolektor yang berhasil dibuat dalam penelitian ini, maka penulis dapat menyimpulkan aplikasi Chatbot Kolektor telah mampu mengatasi permasalahan seringnya gangguan pada sistem pemberi informasi serta mampu melakukan penghematan biaya operasional yang dikeluarkan oleh PT. Indomobil Finance Indonesia.

Saran bagi penelitian berikutnya, pembuatan aplikasi Chatbot Kolektor yang dilakukan dalam penelitian ini sebaiknya dapat disusun juga menggunakan berbagai bahasa pemrograman yang lainnya dalam pembuatan web service. Pengembangan aplikasi chatbot juga dapat menambahkan kecerdasan buatan (Artificial Intelligence) dan Natural Language Programming (NLP) agar chatbot mampu belajar dan menghasilkan knowledgenya sendiri. Pada penelitian berikutnya, pengembangan chatbot yang dilakukan dalam penelitian ini bisa dipergunakan sebagai sebuah acuan untuk dapat mengembangkan aplikasi chatbot di berbagai platform lainnya seperti Whatsapp, dan Telegram

\section{DAFTAR PUSTAKA}

AKHSAN, A. dan FAIZAH, F. 2017. Analisa dan perancangan interaksi chatbot reminder dengan user-centered design. Jurnal Sistem Informasi, 2(13), pp. 7-89.

ANANDA, D. R., FIRDHA, I, YUSUF, M. A. S., dan ARDIANSYAH. 2018. Aplikasi chatbot (milki bot) yang terintegrasi dengan web cms untuk customer service pada ukm minsu. Jurnal Cendikia, XVI, pp. 100-106.

BAGUS, S., ARI, K., dan WIDHI, Y. 2018. Implementasi algoritme blake2s pada json web token (jwt) sebagai algoritme hashing untuk mekanisme autentikasi layanan restapi. Jurnal Pengembangan Teknologi Informasi dan Ilmu Komputer, 2(12).
BENEDICTUS, R. R., WOWOR, H. Dan SAMBUL, A. 2017. Rancang bangun chatbot helpdesk untuk sistem informasi terpadu universitas sam ratulang. EJournal Teknik Informatika, 11(1).

CAROLINA, I. dan ADI, S. 2019. Penerapan Metode Extreme Programming Dalam Perancangan Aplikasi Perhitungan Kuota SKS Mengajar Dosen. Jurnal IKRA-ITH, $3(1)$.

ELISABET, N. S. C. P. and AFRIANTO, M. 2015. Rancang bangun aplikasi chatbot informasi objek wisata kota bandung dengan pendekatan natural language processing. Jurnal Ilmiah Komputer dan Informatika (KOMPUTA), 4(1), pp. 49-54.

HORMANSYAH, D. S. dan UTAMA, Y. P. 2018. Aplikasi chatbot berbasis web pada sistem informasi layanan publik kesehatan di malang dengan menggunakan metode tf-idf. Jurnal Informatika Polinema, 4, pp. 24-28.

JATI, D. dan MAARIF, M. 2018. The development of chatbot application on line messaging platform for customer service in jogja sewa kamera. Compiler, 7(2), pp. 91-98.

JUNADHI dan MARDAINIS. 2019. Line chatbot informasi cuaca wilayah indonesia. Digital Zone: Jurnal Teknologi Informasi Dan Komunikasi, 10(1), pp. 101-109.

KEMP, S. 2020. Digital 2020: Indonesia. [online] Tersedia di: WeAreSocial <https:// https://datareportal.com/digital-inindonesia> [Diakses 26 Januari 2021]

LESTARI, J. 2016. Analisis sistem deteksi kerusakan komputer dengan menggunakan metode forward chaining. Jurnal Inspiraton, 6(1), pp. 19-27.

LINE. 2016. Line announces plans for expanded development and proliferation of chatbots. [online] Tersedia di: <https://linecorp.com/zhhans/pr/news/en/2016/1517> [Diakses 23 Januari 2020]

SETIAWAN, D., 2018. Dampak perkembangan teknologi informasi dan komunikasi terhadap budaya. JURNAL SIMBOLIKA: Research and Learning in Communication Study. 4(62).

SURYANI, D. dan AMALIA, E. 2017. Aplikasi chatbot objek wisata jawa timur berbasis aiml. SMARTICS Journal, 3(2), pp. 4-54.

WIJAYA, M. H., SOTYOHADI, dan SETIAWAN, R. S. 2015. Perancangan chatbot pembelajaran pemrograman berorientasi object berbasis sistem modular. SENATEK (Seminar Nasional Teknologi), 1(A), pp. 379-386. 